IP Periodica Polytechnica Social and Management Sciences

26(1), pp. 49-66, 2018

https://doi.org/10.3311/PPso.10427

Creative Commons Attribution (i)

RESEARCH ARTICLE

\section{How to Keep a Promise: Laymen Answers to the Financial Crisis}

\author{
Kinga Pétervári ${ }^{1 *}$
}

Received 19 December 2016; accepted 23 January 2017

\begin{abstract}
This article is a case study, providing a possible interpretation of the current Hungarian financial-legal culture.

How to apply those terms and conditions in long-term loan agreements in financial crisis, which are favourable or seemingly irrelevant in good times but turn out to be disadvantageous, sometimes even disastrous in bad times. How to calculate and allocate risks, what is acceptable and what is foreseeable to laymen?

The focus here is on the laymen attitudes towards long-term contractual obligations and performances in the global financial crisis: whether debtors' contractual obligations must be fulfilled, what should be construed as an excuse for non-performance, whether there should be measures designed to protect the debtors more, if yes, at whose expense - the creditors (rather preventive measures) or the taxpayers (rather restitutive measures) -, if no, how to allocate ideally the risks and liabilities, is profit-making an evil per se, that needs to be managed?
\end{abstract}

\section{Keywords}

Hungary, financial crisis, long-term loan agreement, credit and financial culture, liability, risk assessment, foreseeability, risk allocation, trust, state, market

${ }^{1}$ Department of Business Law,

Faculty of Economic and Social Sciences,

Budapest University of Techology and Economics,

H-1521 Budapest, P.O.B. 91, Hungary

*Corresponding author, e-mail: petervari.kinga@gmail.com

\begin{abstract}
"Imagine that the keeper of a huge, strong beast notices what makes it angry, what it deisres, how it has to be approached and handled, the circumstances and the conditions under which it becomes particularly fierce or calm...gently or wild.... He calls it knowledge, forms it into a systematic branch of expertise, and starts to teach it, despite total ignorance, in fact, about which of the creature's attitutdes and desires is commendable or deplorable, good or bad, moral or immoral...since he hasn't realised and can't explain to anyone else how vast a gulf there is between necessity and goodness."
\end{abstract}

(Plato: The Republic 493a-c)

\section{Introduction}

This article is about a possible interpretation of the current Hungarian financial-legal culture amongst the students, especially related to the private credits and private loan agreements.

It has been almost a decade since the latest financial crisis grew global. And although this kind of crisis - however different it may have been - is an immanent characteristic of capitalism, there is still a great deal of doubts and uncertainty in the reactions of the (Hungarian) people. How to apply the rules and conditions in the agreements which were favourable or seemingly irrelevant in good times but turn out to be disadvantageous, sometimes even disastrous in bad times. Should they be foreseeable? Foreseeable to whom?

The question whether there is such a thing like ethical economy (Griffiths - Lucas, 1996), has perhaps never been discussed so intensively and challenged so globally (Picketty, 2013), as it is nowadays. The motivation such as "greed is good" has perhaps never been to be hidden behind such a dense drapery. Besides, however, the series of questions of accountability or responsibility (liability) emerge ceaselessly together with analysis, should they be legal (Pázmándi, 2015), political, ethical or cultural (Fleck-Gajduschek, 2015).

There is, certainly, nothing new in the problem of keeping a promise in adverse (economic) conditions. Hungary has also survived many wars, inflations, revolutions and turmoils ${ }^{1}$. The idea of pacta sunt servanda has long been a legal rule of civil

1 See e.g. the Hungarian Legal Journal (Jogtudományi Közlöny) between 1921-1923 for illustrating the problems of performance of long-term contracts under and after WW I. 
law in Hungary too. So it is accepted, that the parties must perform unless the newly emerged (excusable, unforeseeable?) circumstances make it impossible for a party to fulfill the earlier promise, clausula rebus sic stantibus.

Obviously, the existence of such rules, such legal rules, require developed ideas about how individual and/or social risks are to be calculated and allocated (Hatzis, 2015). And further the existence of such rules does not necessarily mean that they are efficiently enforced or applied. The more such rules are part of a legal culture, the clearer it can be the kinds of events which may be unforeseeable (therefore excusable), really unexpected, and which are not.

Lately, the widespread use of long-term private credits (the consumer loans, or the consumer loan agreements) offer good chances to illustrate what people in Hungary think about longterm obligations, responsibility, calculations, financial risks, liabilities, performances and excuses. The relevant question in law is, how likely and how foreseeable the various possible new scenarios (e.g. a global economic financial crisis) or the (non-) expected human reactions - both biologically (e.g. serious illness) and sociologically (e.g. a divorce, or unemployment among - lower - middle class people) - could be. Some of these considerations are inevitable, for the parties entering into a contract, to calculate the risks (in both sides) and thereby allocating the liabilities properly, in other words, to use resources efficiently. If special unexpected changes in the performance or in the circumstances are not foreseeable or not arranged in the agreement properly, then instead of the prior risk minimization rules, the liability for damages must be applied so that to offer efficient remedies ${ }^{2}$.

The following article enquires the laymen reactions upon the above mentioned situations. It analyses the laymen attitudes of the long-term contractual obligations and performance in the global financial crisis: (i) whether the obligations of a loan agreement have to be fulfilled no matter what new circumstances may occur, (ii) whether the original objective of the debtor in a loan agreement makes any difference in case of failure, (iii) what kind of events should be construed as an excuse for non-performance, (iv) whether there should be measures designed to protect the debtors more, (v) if yes, at whose expense - the creditors (rather preventive measures) or

2 It should be emphasized, that the word "responsibility" here is being used in a much more broader sense than it is suggested by András Földi (Földi, 2004) in his book, reviewing (also) the historical conception of responsibility; This, perhaps a little bit overbroad, understanding of responsibility is naturally due to the goal of the questionnaire which is to interrogate the laymen so the respondents are non-law students, therefore their interpretation of responsibility or liability or accountability may not be so distinctive. Also that is why my construction of responsibility here purports to include "cultural responsibility" such as solidarity as well and horribile dictu risk and responsibility might well be used interchangeably, since they are - in certain sense - just the other side of the same relations. the taxpayers (rather restitutive measures), (v) if no, how to allocate ideally the risks and liabilities, and finally (v) whether profit-making is an evil per se, that needs to be managed.

\section{The methodology}

The survey was conducted through several years (between January 2013 and September 2016) among the same, from a statistical point of view, homogenious groups. The questionnaires were to be answered in every semester by the students of the business law course at the very beginning, in the first class. The students are therefore generally among 20-24 years of age and have presumptively different sociological and geographical backgrounds, of course. What makes them comparable though, is their age, their lack of interest to be a lawyer, but their aim to be engineers or economists, their being at the threshold of their professional life and basically their common educational culture at school. This generation was born after the Transition ${ }^{3}$.

Naturally, the questionnaires are anonymous and non-obligatory. The total number of answers so received is close to 400 . The survey seeks to have answers on these students' attitudes towards private expectations, private debts, private bankruptcies, possible state duties and therefore implicitly, about contractual obligations, market failures and perhaps solidarity.

A caveat should be emphasised here, though. Undoubtedly, several hermeneutical doubts may occur, as in any questionnaire, by answering the questions in the different cases or legal situations. Since the aim is to find out the laymen's reactions to the financial crisis, the various terms are actually used in their everyday common understandings, provided that there are any. So here there should be more scenarios (Pázmándi, 2015) to clarify.

First, when using the various legal terminus technicus which have no 'exact' correspondent terminology in the every day life, a broader lay-conception of the terms are to be understood. Thus, for example, there are no distinctions amongst the different long-term loan agreements, whether these cover a consumer credit construction or a lease purchase contract or a sales and purchase agreement. These are to be understood as long term binding obligations.

Second, there are certain legal conceptions which do comply with an everyday meaning but not necessarily to that one what the term would be used for. Consider, for example, the institution of private/individual bankruptcy, which was not even in the public discourse at the beginning of the conducting the survey (see fn. 9 and 11. below). Bankruptcy, as such, is foggy and pejorative in traditional Hungarian common discourse. It might refer to an unworthy release from debt, but could mean a

3 "Transition" here is meant to describe the democratisation and marketisation process of the post-communist societies after the collapse of the Soviet regime in East-Central Europe in the 1990s. 
cunning release from it too. Owe exactly to the very nature of this survey, that the students filled in this questionnaires without having had the chance to distinguish among the various institutions in the questionnaire, this private bankruptcy institution might represent different conceptions or have dubious and vague objectives for the respondents. In any event, this term might not give enough insight into its real meaning in the survey.

Third, in some cases certain pre-conception is already presumed on the part of the respondents. So for example, taking private loan for purchasing further real estates as an investment might qualify as private speculations for some, whereas business investment for others. As a matter of fact who can tell? What makes a business to be a business, from a non-legal point of view? Also, the use of other somewhat vague terms, adjectives, like "luxurious" expenses, however relative their meanings might be, lack the prior clarifications or distinctions too, so they are used as common sense, whatever that might well be (see fn. 7. below).

\section{The basic scenarios}

The whole questionnaire has basically three different groups of questions. The first group of questions is A) what would someone do in case a private debtor (a consumer) fails to perform in a long-term loan agreement concluded for further three very different purposes: i) the purchase of a flat, ii) the purchase of a luxurious sport car or a luxurious vacation, or finally iii) the purchase of real estates as an investment. The second - here not to be discussed - group of questions B) concerns answers, like what would someone say if damage were caused at the workplace and the claim should be against a company (employer) or against an employee. The third group of questions C) deals with the attitudes towards business or rather business failures, and enquires whether the small and medium entreprises (SMEs) should be supported by any regulations steered by the state and eventually what sort of deliberative decision-making would be satisfactory for any business calculation.

The analysis of these data, received from the responding students and processed in a freely accessable PSPP database, provides for the following results.

The basic scenarios of the private long-term loan agreement and the answers pertaining to them are the following (3.1., 3.2., 3.3.). The very first questions of the survey are whether one would help someone else who is in failure of performing a long-term loan agreement, depending on the objective of the spending and the circumstances causing the default.

\subsection{Saving for what?}

According to the first scenario, in which a flat was purchased, the indebted person failed, despite of his precautious acting by having calculated possible risks and costs well before the decision. He has failed due to the global economic and financial crisis and because his employer was wound up so he also looses his good job. The majority of the answers voted for help. (yes: $63.13 \%$ - no: $32.96 \%{ }^{4}$ ).

When the same question concerned a slightly different situation, namely, that the failure to perform was due to the fact that the debtor's wife got ill, and so needed more care that cost a lots of money and time, so he loses his job, the willingness of help even raise higher. (yes: $84.64 \%$ - no: $11.73 \%$ ).

On the other hand, when the pay back of the loan is stopped because the couple decides to divorce and that proves to be too expensive, the helping intentions decrease dramatically. (yes: $20.95 \%$ - no: $74.58 \%$ ).

So far it may be said that the respondents are quite sympathetic to the debtors. It is well accepted to use credit for buying a place to live in even if one is without the means to do that. This may reflect the spirit of the post-socialism too, that the minimum level of existence may also include housing. Not many would think that this should not be so $(\sim 33 \%)$ but it is also not to conclude that these people would say that prior saving is the answer to such problems ${ }^{5}$. One thing is clear though, that respondents do punish those, who get into trouble upon their own faults, whatever this might mean. Obviously, the divorce is such a thing, whereas getting sick, of whatever kind, is not. In any event, these results should be read cautiously. The respondents are young, without own experience of the nature of a marriage and the diseases at all.

\subsection{Helping but how?}

In the next scenario, this first question is endowed with a different background. The aim of the loan is different, thus the debtor, under the same circumstances, wishes to acquire a luxurious sport car or a luxurious vacation ${ }^{6}$, instead of a flat for the family. The failure of performance is however the same. Firstly, in case of the global financial crisis, the willingness to help the debtor is (relative to the above) very low. (yes: $14.53 \%$ - no: $82.40 \%$ ).

Secondly, however, when the failed performance is due to the illness of the spouse, the wanted help is higher again. (yes: $54.75 \%$ - no: $42.18 \%$ ).

Thirdly, the vast majority refuses to help in the event of a divorce. (yes: $12.01 \%$ - no: $84.64 \%$ ).

The respondents are seemingly less sympathetic with the idea of a luxurious spending financed out of a loan. However it is still robustly accepted and supported if someone fails due to illness ( $\sim 55 \%$ would help). It seems, that illness is regarded as an utterly bad and unjust fate, no matter why and how, which must be remedied.

4 Please note, that a few answer was illegible or missing, therefore the total of "yes" and "no" shall not be $100 \%$.

5 Quite certainly, there is no such question about savings, since otherwise the respondents would have reacted in a biased way.

6 'Luxury' might have meant 'greed' to some but 'necessity' to others. Assumedly, the answers reflect the distinctions. 
Clearly, however the objective of the spending (out of loan) makes quite a difference.

\subsection{What is the role of responsibility?}

In the final scenario, the loan is used differently again. Instead of buying a flat or getting a luxurious car or entertainment, the aim here is to purchase further real estates as investments for the future.

If global financial crisis caused the debtor to fail the performance, a substantial majority of the respondents would say "no" to a helping request here. (yes: $24.58 \%$ - no: $72.35 \%$ ).

If however the spouse's illness were the reason to stop paying back the loan, the respondents would be more willing to help. (yes: $62.29 \%$ - no: $33.52 \%$ ).

In case of divorce, on the other hand, this helping willingness plummets again. (yes: $13.41 \%$ - no: $80.73 \%$ ).

Interestingly enough, if one takes a closer look at the results of these three basic scenarios, it is striking what differences there are in the anwers.

Table 1 Causes of failures compared

\begin{tabular}{llll}
\hline $\begin{array}{l}\text { Yes for help in } \\
\text { housing }\end{array}$ & $\begin{array}{l}\text { Yes for help } \\
\text { in luxurious } \\
\text { spending }\end{array}$ & $\begin{array}{l}\text { Yes for help in } \\
\text { further real estate } \\
\text { as investment }\end{array}$ & $\begin{array}{l}\text { Cause of } \\
\text { failures }\end{array}$ \\
\hline $63.13 \%$ & $14.53 \%$ & $24.58 \%$ & $\begin{array}{l}\text { global crisis } \\
\text { illness of } \\
\text { spouse } \\
\text { divorce }\end{array}$ \\
\hline
\end{tabular}

It seems to be important for the respondents what the aim of the long-term loan agreement is, and whether it is so justified, so as to be worth a common help. The minimum living existence (i.e. housing) is clearly more worth than a luxurious spending or a speculation as an investment. In any event, the respondents are also reacting on the variety of the causes of failures. The global financial crisis triggers help but much less than illness does.

It might well be the case that for these youngsters a divorce is such an overriding self default, that it is not worth futher inquiries what the circusmtances are/were. And it is true on the other way around, i.e. the spouse's illness is such a devastating impact that should be outweighed with help, again, regardless to the circumstances.

The questionnaire consisted of further inquiries related to the above mentioned scenarios, digging for the "why"s and the "how"s of the plain "yes" and "no" answers. The basic scenarios remaining the same, the later answers are analysed in relation with the earlier ones. So these cross references are supposed to show what a respondent would say for further questions if at the start he decided for yes, for helping those in financial need, or on the other way round, what a respondent would say for further questions, if at the start he decided for no, for not helping those in financial need. Therefore the tables below (Table 2-4) demonstrate also a cross reference scrutiny to the very questions, in which the first line of anwers indicate whether the respondent would help (yes) or would not (no). Corollary, it means that the responses in the rows are related to the responses in the columns (yes-no).

\section{The analysis}

As a base line results here are the most important assessments concluded during the survey, subject to the analysis and evidences, of course, as hopefully provided below.

4.1. One can hardly distinguish among the respondents as to their attitude towards the state and the free market. Distrust in both institutions is just almost palpable.

4.2. The market rules are selectively accepted. In case of market failure the solutions are generally implicitly expected from the state.

4.3. Readiness to help others in need is relatively widespread if and only the cause is not self-inflicted and the spending is justified.

4.4. However well acknowledged it is, that market failures are indispensable, the expected cure from the state regulations are just not trusted.

\subsection{One can hardly distinguish among the respondents as to their attitude towards the state (and the free market). Distrust in both institutions, market and state, is just almost palpable.}

Firstly, the question is, what do the respondents think, when to help, indeed, what sort of deliberation is to be concerned in the decision-makings. (The role of private savings).

In the first question, our fictitious debtor might have been a responsible person and besides the loan, he would make some savings too. So he would take care of his own pension, private health service and future education for his children. In these cases a new question arises in all scenarios, namely, whether the respondent would reconsider his willingness or refusal to help, if he knew that the debtor could not pay because he has saved (or is just saving) money for retirement, illness and education for his children.

In the case of a global financial crisis the answers are the following (Table 2/A).

In Aa) case, i.e. when the debt is spent on a flat to live in, those who would help in the first place, would more likely reconsider their positive answer than those who would not support the debtor at all. It should be noted here, that the "yes" group formed quite the majority, i.e. $63.13 \%$ of the respondents. So it seems, that almost half $(42.11 \%)$ of the respondents ready to help in need, would not assist to the debtor, if they knew, the debtor had savings (no matter what sort of savings). 
Table 2 Saving for what?

Minibrain has an average but well-paying job, which allows him to make plans for long-term future as well. He and his wife live with their 2 minor kids together.

A/a) They want a bigger flat, because they still live at Minibrain's parents. So he calculated that since he cannot afford to buy a flat. he takes a loan, which he later fails to pay in due instalments, and while his flat is going to be auctioned, the rest of the debt is still to be paid back

If he failed because his employer is wound up due to the global economic crisis.
A/b) Minibrain wants to have a sportcar/a luxury vacation and calculates that even if he had such a solid financial background he would not be able to cover such an expense. So he takes a loan which he later fails to pay in due instalments, and while his flat is going to be auctioned, the rest of the debt is still to be paid back.

If he failed because his employer is wound up due to the global economic crisis.
A/c) Minibrain thinks it is a good investment to purchase further real estates, to lease them or later to sell them for more. So he takes a loan which he later fails to pay in due instalments, and while his flat is going to be auctioned, the rest of the debt is still to be paid back

If he failed because his employer is wound up due to the global economic crisis,

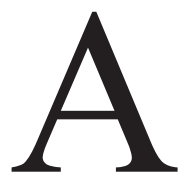

\begin{tabular}{|c|c|c|c|c|c|}
\hline \multicolumn{2}{|c|}{ Would you help him? } & \multicolumn{2}{|c|}{ Would you help him? } & \multicolumn{2}{|c|}{ Would you help him? } \\
\hline yes & no & yes & no & yes & no \\
\hline $63.13 \%$ & $32.90 \%$ & $14.53 \%$ & $82.40 \%$ & $24.58 \%$ & $72.35 \%$ \\
\hline
\end{tabular}

Would you reconsider

it, if he could not pay because he saved money for retirement, illness yes $42.11 \%$ $9.20 \%$ $50.19 \%$ $1.10 \%$ $38.94 \%$ $8.51 \%$ and education for his children?

\begin{tabular}{|c|c|c|c|c|c|c|c|}
\hline & & \multicolumn{2}{|c|}{$\begin{array}{l}\text { If he failed because his wife got } \\
\text { seriously ill and the treatment is ex- } \\
\text { pensive, time consuming and finally } \\
\text { he looses his job too. }\end{array}$} & \multicolumn{2}{|c|}{$\begin{array}{l}\text { If he failed because his wife got } \\
\text { seriously ill and the treatment is } \\
\text { expensive, time consuming and finally } \\
\text { he looses his job too. }\end{array}$} & \multicolumn{2}{|c|}{$\begin{array}{l}\text { If he failed because his wife got } \\
\text { seriously ill and the treatment is } \\
\text { expensive, time consuming and } \\
\text { finally he looses his job too. }\end{array}$} \\
\hline & & \multicolumn{2}{|c|}{ Would you help him? } & \multicolumn{2}{|c|}{ Would you help him? } & \multicolumn{2}{|c|}{ Would you help him? } \\
\hline & & yes & no & yes & no & yes & no \\
\hline & answer & $84.64 \%$ & $11.73 \%$ & $54.75 \%$ & $42.18 \%$ & $62.29 \%$ & $33.52 \%$ \\
\hline \multirow[t]{5}{*}{$\begin{array}{l}\text { Would you reconsider } \\
\text { it, if he could not pay } \\
\text { because he saved money } \\
\text { for retirement, illness } \\
\text { and education for his } \\
\text { children? }\end{array}$} & yes & $44.44 \%$ & $9.79 \%$ & $11.79 \%$ & $9.79 \%$ & $34.25 \%$ & $4.55 \%$ \\
\hline & & \multicolumn{2}{|c|}{$\begin{array}{l}\text { If he failed because he and his wife } \\
\text { decide to divorce and the facilitation } \\
\text { of the two separate lives imposes } \\
\text { significant financial burden. }\end{array}$} & \multicolumn{2}{|c|}{$\begin{array}{l}\text { If he failed because he and his wife } \\
\text { decide to divorce and the facilitation } \\
\text { of the two separate lives imposes } \\
\text { significant financial burden. }\end{array}$} & \multicolumn{2}{|c|}{$\begin{array}{l}\text { If he failed because he and his wife } \\
\text { decide to divorce and the facilita- } \\
\text { tion of the two separate lives im- } \\
\text { poses significant financial burden. }\end{array}$} \\
\hline & & \multicolumn{2}{|c|}{ Would you help him? } & \multicolumn{2}{|c|}{ Would you help him? } & \multicolumn{2}{|c|}{ Would you help him? } \\
\hline & & yes & no & yes & no & yes & no \\
\hline & answer & $20.95 \%$ & $74.58 \%$ & $12.01 \%$ & $84.64 \%$ & $13.41 \%$ & $80.73 \%$ \\
\hline $\begin{array}{l}\text { Would you reconsider } \\
\text { it, if he could not pay } \\
\text { because he saved money } \\
\text { for retirement, illness } \\
\text { and education for his } \\
\text { children? }\end{array}$ & yes & $34.02 \%$ & $12.10 \%$ & $31.39 \%$ & $8.43 \%$ & $43.61 \%$ & $9.99 \%$ \\
\hline
\end{tabular}


Seemingly, the $\mathrm{Ab}$ ) case is not much of a difference. In $\mathrm{Ab}$ ) case, i.e. the luxurious spending case, a little more than the half (50.19\%) of the "yes" respondents would reconsider the help and would be far less sympathetic with the debtor, if he knew about the savings. Here the odds is however, that this "little more than half" relates to a much less group of the respondents, the $14.53 \%$ original "no" group (as opposed to the 63.13\%). So it means, that the pattern is the same: the half of the 'yes' majority would reconsider the answer. But the multitude here is much less. These figures make difference only in relation to the total responding population. In $\mathrm{Aa}$ ) those who would reconsider their positive answers are $25 \%$ of the respondents whereas in $\mathrm{Ab}$ ) only $7 \%$.

Finally, the reconsideration of the 'yes' group is the least likely in case Ac), in which investments/speculations are the target of the loan. However, the difference between Aa) and Ac) seems to be within just a margin of deviation $(42.11 \%$ vs. $38.94 \%$ ). But this $38.94 \%$ is counted from the $20.95 \%$ "yes" of the original help group as opposed to that of the $74.58 \%$ "no". Nevertheless, the pattern is resembling to that of $\mathrm{Aa}$ ) and $\mathrm{Ab}$ ).

To add it all up, one could draw the conclusion, that those who would not help in the first place at all - no matter whether they are in the majority or in the minority - would be less likely to reconsider their answers. And here, this point must be stressed even more. Because, the question could be construed the other way round, so that to emphasise that although one would not help right away, but would do so, nonetheless, upon learning that the debtor failed because he had had savings, thus the debtor proves to be a rational one, worthy of support. It seems that this kind of interpretation did not occur.

Conspicuously enough, when the failure to perform is due to the spouse's illness, the answers look very very different (Table 2/B). The luxurious spending in case of the illness of the debtor's wife is the least favourable, therefore the least supportable deed among all things. The swings of reconsideration or not, i.e. the saying of "no" help instead of "yes" help, is the highest. (see Ab) in Table 2/A: $50.19 \%, \mathrm{Ab}$ ) in Table 2/B: $11.79 \%$, and $\mathrm{Ab}$ ) in Table 2/C.: 31.39\%). Nevertheless it should be borne in mind that these figures are very little if related to the total responses: they range from $\sim 5.5 \%$ to $\sim 7 \%$.

And finally, if the stoppage of pay back is owe to the divorce, the results are as expected, (relatively) in accordance with the first scenario, i.e. in the case of global financial crisis (Table 2/C.). The difference however is still, that the original "yes" groups are smaller in this case, than in the housing provision case. That should definitely mean, that this investment/ speculation is rather regarded as business or as speculation which in failure would not worth public help.

One way to think about this, is that whatever the differences there might be, these data show little respect to the reasons why someone gets into trouble other than illness or divorce in the first place. As opposed to that, the very reason, that someone does have the aim to take care of himself and also of his family, matters little. Thus one inevitably gets to the conclusion, that (financial) responsibility, (financial) autonomy, thereby freedom (of the state?) means little among young respondents.

Another way to analyse these data, and it is remaining certainly unproven here, is whether or not these reconsiderations mean that the respondents look at the situation not as a sign of responsibility, but as a sign of financial capability of the debtor to pay out his debt. This attitude may therefore be interpreted as a manner mirroring a pure market answer. No one is in need who still has savings.

However, if this speculative thinking is right, this train of thought might also reflect a kind of lack of institutional thinking (in financial matters). First of all, long-term savings may not necessarily guarantee liquidity. Second of all the bridging loans are designed also for exactly this kind of situations. Terminating a long-term savings contract before it is due, is not less of a damage than it is not to perform on time an installment of paying back a loan. If someone takes into consideration that long-term savings are delayed demands, then as a matter of social efficiency, the help in such a need should be, or may be, tackled with differently. Corollary, the discrepancy here between social justice and economic efficiency may be found to be false, but not for the respondents.

Besides it should be noted, however, that in general, it is not acceptable, as such, if someone without the means asks a loan for luxurious spending. And this remains even then so, when it turns out that the debtor had savings nonetheless.

And this is absolutely different from the case, in which sickness is involved in the failure of the performance. Certainly, this traditional view and this traditional ambience of sickness may seem anachronistic: "if you are ill, stay in bed". But, clearly, there are so many kinds of illness. Also, one should consider, that in Hungary, the health insurance is part of the state budget, however separate, and the contribution is collected as tax revenue. Illness is therefore already regarded as a living on public funds. No need for further support in case of luxurious expenses. Or it may be construed, in the contrary, that it is well justified (accepted) that ill people should be subsidized out of the public funds. But/or, corollary, people in Hungary have the impression, as a matter of fact, that ill people are generally poor or may become very quickly as one.

Brifely comparing these results for the sake of a possible conclusion, one might add the following doubts. The real question of the survey here was supposed to enquire the idea of self-support, or savings attitudes. It seems that the respondents would be more likely to help those in need who lack the means to get out of the financial problem. So far, so good. Since the here advocated help of the respondents proves to be, implicitly, state subsidized intervening measures (see below), it certainly causes some stress on the public budget, therefore this answer seems to be economically correct, efficient and pacifying. Those who have savings should use it first and then be aided by the community. 
There are many distinctive and delicate ramifications of this attitude though. One is political, i.e. however this conclusion might be true, voters tend to think differently. (And this is so despite the fact that one could say the students represent rather the middle class than the lower or the lowest strata of the society or of the voters.) The other one is financial and not less complicated. If one really ponders on the original question here, it should be obvious, that these kinds of savings are not at all (or not necessarily) big monies or significant wealths. These may rather be considered as conscious behaviour of the middle class civic virtue attitude, to act as a financially independent individual. An individual of its lockean or even kantian sense and an independence in its conception as that of the enlightenment. So perhaps confusingly enough, to conclude that precisely those should be helped who lack the possibility to survive a financial crisis at the expense of those who have made certain savings just in order to avoid exactly this financial trap - proves to be the trick of the reason. This kind of solutions therefore may become counter-productive. There seem to be no motivation at all to act financially responsible ${ }^{7}$. The third one is a sociological consideration, or educational for that matter. There is no doubt that only the most vulnerable needs to be protected in case of financial need and that it should be done even through the public assistance, i.e. the public budget. And it is true as well, of course, that this help may only be carried out at the expense of those, who are not in financial trouble, or less hurt by the crisis for whatever reason. Although it is all a matter of degree too. Notwithstanding, this kind of thinking creates a political-economic circulus vitiosus, which needs to be broken. And it can be done only through education (whatever that might mean, for generations to come or learning from scratch for every generation).

Secondly, the question is, helping but how. (The role of bankruptcy or preferential tax regime).

The specific questions here concern two separate issues. Both of them may qualify as measures of definite state interventions but they put the burden of losses differently on the loss bearers. One of the questions is whether the respondent would support an individual bankruptcy for the debtor, the other one is whether the respondent would support a preferential tax system for private debtors. If one accepts the idea of individual bankruptcy, i.e. supports it, however intrusive it might be into the private sphere of the contractual parties, the losses nevertheless are still to be born by the parties to the contract themselves. It is merely a new risk allocation which is being (re)negotiated in a case like this. On the other hand, if one promotes a preferential tax system for the private debtors, then he goes along with a distribution of losses among the taxpayers, which means among third parties, outsiders, to the contract.

7 This kind of arguments are also often used in the debates when the principles of the income tax regime is discussed: proportional, linear, fixed, etc. (Byrne, 1999 or Schoenblum, 1995).
In any event, the real question in law is whether these longterm contractual obligations are binding no matter what, or there should be certain possibilities to the parties for renegotiations. If this latter were accepted, then the exact procedure should be laid down in advance, so that business calculations were possible. As a matter of fact, in private debts, one recognizes the rules of the consumer protection laws here, providing for the room for maneouver in advance, in which the parties may (fairly) reorganise their rights and duties, such as amending the contract or terminating the contract, etc.

The individual bankruptcy ${ }^{8}$ however, is not the legal institute per se of the consumer protection. Since this allows, or rather facilitates, the renegotiations between the parties under strictly regulated circumstances, this is a much harsher state intervention forcing the creditors to enter into a new agreement if the private debtor unilaterally so requested. Good such law may create a win-win position however, thus it is not entirely a market unfriendly legal institution. The losses are taken by the parties themselves according to their new, certainly not quite regulation-free, agreement.

As opposed to that, the preferential tax system for private debtors, distorts the markets. One could certainly add that preferential tax system does exist in free markets as well, so to distinguish this legal institution, might be a little problematic for youngsters. Because what may fit to the business investments, may not be so for private spenders. The nature of their costs, the social costs are different, the (social) effectivity of the concluded but so failed private contracts is dubious ${ }^{9}$. Free market can deal with external costs if and only there is no better solution for the socially desired contractual relations, see national defence or clean air, etc. But private spending is very different and may trigger many more problems beyond reach of this survey, such as biased administrative decisions (corruption) or misrepresentation, etc.

One way of looking at the tables above (Table 3/A-3/C.), is to ask, how binding these long-term contractual obligations are to the debtors according to the respondents ${ }^{10}$. Not very much surprisingly, those who originally responded positively to help out those in financial need, answer overwhelmingly positive also to the questions whether they would support various state interfering measures.

8 See also the Act No CV of 2015 on the bankruptcy procedure of natural persons. This statute introduces the individual / private bankruptcy for the first time ever in Hungary as of September 2015.

9 But of course requires concerns. No one likes homeless people lingering around.

10 Sadly enough, the answers may be confusing (the questions might have been confusing too), especially when compared with the third/last question in the line below (see there). Since the institution of private bankruptcy was non-existent even in the public discourse until mid-2015, its conception must have been a vague and broad idea of the respondents, meaning a special kind of termination of the contractual relation from 2013 to 2015 . This reflects speculation of course, supported only by teaching experiences rather than data. The students in class at the beginning can hardly distinguish a winding up or a bankruptcy, let alone a private/individual bankruptcy. 
If the performance failed because of the worldwide financial crisis, the majority of the respondents would support the help even with certain state intervention such as the individual bankruptcy and a little less intensively with the preferential tax regime ${ }^{11}$; see Aa) (Table 3/A). The pattern is somewhat similar in case of luxurious expenses, provided that one bears in mind that here the original "yes" group is the minority $(14.53 \%)$; see $\mathrm{Ab}$ ). The interesting situation is the question of investment/ speculation. As known, here the vast majority would say "no" $(72.35 \%)$ and the vast majority of this $(73.78 \%)$ says "no" to the preferential tax system as a measure to help in need as well; see Ac). On the other hand the support of the private bankruptcy is the highest in this group. Clearly, this scenario is regarded as business not worthy of help from public monies.

Having the above mentioned in mind, not surprisingly, this willingness to help is much much higher when the pay back was stopped due to the fact that the debtor's spouse had become ill. The exception is again the luxurious expense in case of illness (Table3/B.). It is perhaps obvious, that the average respondent puts the blame on the creditors here. Why was money lended at all? Was it for profit? The further question occurs here though, whether respondents are able to distinguish the cases where the debtor is being sick at the time of entering into the contracts from those cases of getting the serious illness later, during the time of effectivity of the contract. Distincitions like these ones, are hard to be reflected in this survey, of course, especially because the respondents are students, who are quite likely not to have personal experiences with contracts, negotiations, and more importantly with the alleged prudential activities of the creditors.

However, still there are quite a few, who believe that in case of basic housing problems for those in need the preferential tax system may be a solution, i.e. almost the half of the overwhelming majority ( $44 \%$ of the $84.64 \%$ "yes" group, since $55.56 \%$ said no).

If the contract were breached because the debtor had divorced (Table 3/C.), the figures are again substantially less in favour of the debtors just as in the cases where the results reflect own faults. If help were to be granted though, there would be no significant differences whether to support the individual bankruptcy or the preferential tax regime.

All in all, the responses to the "help but how" is supposed to answer the question of how to be released from a debt, how to be free from an obligation taken upon voluntarily.

11 Please note, that the tables (Tables 3/A-3/C.) show the "yes" in the first row and the "no" in the second row. Therefore, in the second ("no") row the opposite results are to be calculated. Albeit this might be more obscure and harder to interpret, the reason why these tables nevertheless use this sort of form is that this might reflect the first impression better, namely that those who would help, would trust the market less, therefore presumably support individual bankruptcy as opposed to the preferential tax regime. Here thus the comparison would like to rely heavily on the expectations of the state duties.
On the one hand, the responses here are in the line of the above mentioned findings again, namely, that basically the half of those who said "yes", would not support preferential tax system, meaning, that the help should not necessarily be provided for by the state budget. These results may trigger the interpretation that the respondents may well be aware of their personal financial interests as taxpayers in not advocating a preferential tax regime for the debtors in failure.

On the other hand, the idea of individual bankruptcy, however unclear this institution for the respondents might have been, seems to be quite as popular (or unpopular) for solving the problem as the preferential tax regime is, albeit in a way this allows the debtor to be released from his duties at the expense of the creditors rather than the taxpayers.

Since individual bankruptcy is rather missing in the public discourse the respondents might have been less familiar with this, and especially with its operation and aim. As a general conclusion, it could be confirmed though, that except for the minimum existing expectations, i.e. the provision of housing to those in need, where the majority would be the most sympathetic towards the debtors, the respondents are not very much in favour of these kinds of measures, or they are quite split on it, to say the least. Thus, in brief, this would just strengthen the main characteristic result of the survey, meaning that the respondents equally lack the trust in both the state and the market solutions.

And thirdly or finally, one of the most intriguing questions, not only for lawyers, is the following one: whether the profit making is an evil per se. (The role of responsibility, and not only for bad economic decisions).

Whether it is acceptable that the market situations are not necessarily win-win positions and so if there are bad financial calculations, the outcome of the decisions needs to be borne by the decision-maker. Or quite to the contrary, whether there should be a mandatory state correction for market failures, so that to insulate decision-makers from the consequences of their own decisions.

This allows to ask whether the long-term loan agreement is to be (may be) terminated because of the problems having occurred on the debtor's side but far beyond the debtor's reach. It means that certain events, such as war, epidemy, natural disaster, global financial crisis, uprise, revolution, etc., may not be the doing of either party, still they have the almost unendurable impact on them or only one of them. Should it matter to us, if only one party suffers from the devestating affect, or if one of the party is better off, while the other is ruined owe to the changes in the circumstances, or should it not. In case of a private long-term loan agreement, there is no doubt, that the creditor undertakes a substantial risk, since the creditor generally does perform at once upon signing the contract, whereas the debtor has time to pay back. And this separation of deliveries of the parties to the contract, this discrepancy allowed by time, would make the risks of the parties unbalanced, unless specific guarantees are provided for in the terms and conditions otherwise. 
Table 3 Helping but how?

Minibrain has an average but well-paying job, which allows him to make plans for long-term future as well. He and his wife live with their 2 minor kids together.

A/a) They want a bigger flat, because they still live at Minibrain's parents. So he calculated that since he cannot afford to buy a flat. he takes a loan, which he later fails to pay in due instalments, and while his flat is going to be auctioned, the rest of the debt is still to be paid back

If he failed because his employer is wound up due to the global economic crisis.

Would you help him?
A/b) Minibrain wants to have a sport-car/a luxury vacation and calculates that even if he had such a solid financial background he would not be able to cover such an expense. So he takes a loan which he later fails to pay in due instalments, and while his flat is going to be auctioned, the rest of the debt is still to be paid back.

If he failed because his employer is wound up due to the global economic crisis.
$\mathbf{A} / \mathbf{c})$ Minibrain thinks it is a good investment to purchase further real estates, to lease them or later to sell them for more. So he takes a loan which he later fails to pay in due instalments, and while his flat is going to be auctioned, the rest of the debt is still to be paid back

If he failed because his employer is wound up due to the global economic crisis,

global economic crisis,

Would you help him?

\begin{tabular}{|c|c|c|c|c|c|c|c|}
\hline & & \multirow{2}{*}{\multicolumn{2}{|c|}{ Would you help him? }} & \multirow{2}{*}{\multicolumn{2}{|c|}{ Would you help him? }} & \multirow{2}{*}{\multicolumn{2}{|c|}{ Would you help him? }} \\
\hline & & & & & & & \\
\hline & & yes & no & yes & no & yes & no \\
\hline & answer & $63.13 \%$ & $32.90 \%$ & $14.53 \%$ & $82.40 \%$ & $24.58 \%$ & $72.35 \%$ \\
\hline $\begin{array}{l}\text { Would you support an individual } \\
\text { bankruptcy? }\end{array}$ & yes & $55.34 \%$ & $15.30 \%$ & $65.96 \%$ & $5.20 \%$ & $48.08 \%$ & $32.30 \%$ \\
\hline $\begin{array}{l}\text { Would you support a preferential tax } \\
\text { system for debtors? }\end{array}$ & no & $48.80 \%$ & $19.70 \%$ & $58.17 \%$ & $7.90 \%$ & $46.63 \%$ & $73.78 \%$ \\
\hline
\end{tabular}

\begin{tabular}{|c|c|c|c|c|c|c|c|}
\hline & & \multicolumn{2}{|c|}{$\begin{array}{l}\text { If he failed because his wife got } \\
\text { seriously ill and the treatment is } \\
\text { expensive, time consuming and } \\
\text { finally he looses his job too. }\end{array}$} & \multicolumn{2}{|c|}{$\begin{array}{l}\text { If he failed because his wife got } \\
\text { seriously ill and the treatment is } \\
\text { expensive, time consuming and } \\
\text { finally he looses his job too. }\end{array}$} & \multicolumn{2}{|c|}{$\begin{array}{l}\text { If he failed because his wife got } \\
\text { seriously ill and the treatment } \\
\text { is expensive, time consuming } \\
\text { and finally he looses his job } \\
\text { too. }\end{array}$} \\
\hline & & \multicolumn{2}{|c|}{ Would you help him? } & \multicolumn{2}{|c|}{ Would you help him? } & \multicolumn{2}{|c|}{ Would you help him? } \\
\hline & & yes & no & yes & no & yes & no \\
\hline & answer & $84.64 \%$ & $11.73 \%$ & $54.75 \%$ & $42.18 \%$ & $62.29 \%$ & $33.52 \%$ \\
\hline $\begin{array}{l}\text { Would you support an individual } \\
\text { bankruptcy? }\end{array}$ & yes & $61.81 \%$ & $25.83 \%$ & $16.39 \%$ & $25.83 \%$ & $51.57 \%$ & $21.29 \%$ \\
\hline \multirow[t]{5}{*}{$\begin{array}{l}\text { Would you support a preferential tax } \\
\text { system for debtors? }\end{array}$} & no & $55.56 \%$ & $81.03 \%$ & $14.73 \%$ & $81.03 \%$ & $42.36 \%$ & $84.21 \%$ \\
\hline & & \multicolumn{2}{|c|}{$\begin{array}{l}\text { If he failed because he and his } \\
\text { wife decide to divorce and the } \\
\text { facilitation of the two separate } \\
\text { lives imposes significant } \\
\text { financial burden. }\end{array}$} & \multicolumn{2}{|c|}{$\begin{array}{l}\text { If he failed because he and his } \\
\text { wife decide to divorce and the } \\
\text { facilitation of the two separate } \\
\text { lives imposes significant } \\
\text { financial burden. }\end{array}$} & \multicolumn{2}{|c|}{$\begin{array}{l}\text { If he failed because he and his } \\
\text { wife decide to divorce and the } \\
\text { facilitation of the two separate } \\
\text { lives imposes significant } \\
\text { financial burden. }\end{array}$} \\
\hline & & \multicolumn{2}{|c|}{ Would you help him? } & \multicolumn{2}{|c|}{ Would you help him? } & \multicolumn{2}{|c|}{ Would you help him? } \\
\hline & & yes & no & yes & no & yes & no \\
\hline & answer & $20.95 \%$ & $74.58 \%$ & $12.01 \%$ & $84.64 \%$ & $13.41 \%$ & $80.73 \%$ \\
\hline $\begin{array}{l}\text { Would you support an individual } \\
\text { bankruptcy? }\end{array}$ & yes & $52.05 \%$ & $31.50 \%$ & $50.65 \%$ & $29.22 \%$ & $49.62 \%$ & $26.97 \%$ \\
\hline $\begin{array}{l}\text { Would you support a preferential tax } \\
\text { system for debtors? }\end{array}$ & no & $59.02 \%$ & $74.82 \%$ & $44.82 \%$ & $79.22 \%$ & $49.62 \%$ & $79.15 \%$ \\
\hline
\end{tabular}


But what sort of events may be excusable or foreseeable and what others not? The respondents in this survey, seemingly, decided that global financial crisis or illness are excusable, thus may trigger a rearrangement of the risk allocations. Divorce, on the other hand is not (see tables above). Now, why are they excusable? Does this mean that financial crisis and illness are unforeseeable and divorce is not? Nevertheless some would definitely say that divorce is much more foreseeable in the modern western culture than epidemy. Whereas there, certainly, are regions on earth, (even in Hungary too, nowadays) where the opposite should be true.

Here are the results for the case of failure to perform in global financial crisis (Table 4/A). It shows clearly, that the majority would help in need (63.13\%) and the overwhelming majority of these respondents who say "yes" to the help, would not agree with an interpretation that the creditors are profiteers. Therefore only the $7 \%$ of all respondents would say the contracts are not to be paid back. So, implicitly, they do not seriously mean that the contracts should not be fulfilled.

But who should have the burden of failure then? Notwithstanding, if one looks at the other figures of the "no" group $(32.9 \%)$, here the overwhelming majority is more inclined to blame the creditors (only $28.3 \%$ says no), and probably let the parties negotiate (see Aa) in Table 4/A) But these figures are also miniscule, i.e. $7 \%$ of all respondents. In case of the luxurious expenses the respondents have not too much of the solidarity. $82.40 \%$ would not help in the economic crisis for these spendings but would implicitly blame the creditors. Although only $9.80 \%$ of the $82.40 \%$ (these are the "no"-s) of these "no" respondents would say that the creditors are not usurers and the contractual obligations should be fulfilled, but this is $7 \%$ of the total answerers again.

But who are the creditors? Banks, financial institutions, friends or employers, state, perhaps? And when are they the creditors? After having helped out a debtor in need with a bridging loan in a financial global crisis?

This is fairly different in the case, in which the failure to perform is due to the wife's illness and the spending out of loan covered luxurious entertainments (Table 4/B).

Here it seems to be obvious that the majority would feel solidarity for ill people, but would not support a luxurious expense, if someone is ill. In fact, this has been the case above (and here, see Table 4/C) too if one looks at the figures of luxurious expenses being cross referenced with the illness of the debtor's wife. Nevertheless, here it is more conspicuous than anywhere else, but for the above table (Table 4/C), that it is not at all clear whether the repondents believe, the creditors should have the burden of risk. In conjunction with what was said above about the attitude towards the problems of deseases though, the respondents here hold the creditors more liable for lending money irrationally, or lending rather for profiteering.
This interpretation raises further legally more relevant questions: when should an event be foreseeable for which one has to take the liability in a contractual relation. In case of a long-term loan agreement, the answer should clearly be that right at the entering into the contract.

The reason for this is the elapse of time between the exchange of performances of the contractual parties (Csehi, 2015) ${ }^{12}$. Thus sickness may only be foreseeable if the circumstances in the given case so suggest. Seemingly, the repondents here think, that the probability of a serious sickness is higher than that of the (global) financial crisis or of the divorce, as a matter of fact. Therefore the creditor bears the risk for sickness, since the creditor should have known it better and/or calculated it.

Even if it were true that the Hungarian people are generally sick, it should also be a common sense knowledge, that in every 20 years of an investment or a loan agreement or whatever, there will be at least 5-7 bad years too.

Perhaps, of course, it can also be construed, that the case of the divorce is not that it is unforeseeable $\mathrm{e}^{13}$, but that it is own fault (Table 4/C). The figures in this divorce case are again different, but certainly in comfort with the other anwers in the previous cases (Table 3/C.), where the pay back is stopped by the divorce of the debtor.

As an average, the respondents feel like helping is necessary for the failing debtors, unless the debtors' situation can be attributed to their own fault, such as divorce. This exception of divorce may however derive from the young and idealistic age of the respondents rather than represents a social exclusion.

\subsection{The market rules are selectively accepted, in case of market failure the solutions are generally implicitly expected from the state.}

The processed data in the tables above (Tables 1-3) have further implications. The answers design a relatively ambiguous pattern about whether an obligation needs to be performed in the long run and who is to bear the burden of failure. Notwithstanding that the vast majority of the respondents accept that the creditors (banks?) are not profiteers or usurers as seen in tables above (Tables 3/A$3 / \mathrm{C}$.), yet, only a few of them would go along with the consequences of such a decision. This straightforward conclusion however needs some clarifications and distinctions, of course.

Albeit depending on the situation, the majority would be willing to help in the case of the basic housing problems even if the overwhelming majority of these respondents would not

12 This foreseeability and the damages problems may certainly be different if the contract is about management services (Csehi, 2015).

13 According to the statistics (KSH, 2013.), in the last three decades the numbers of the divorces in Hungary were the following: 1990: 24.888, 2000: 23.987, 2012: 21.830, 2013: 20.000 (estimate) and the number of the marriages: 1990: 66.405, 2000: 48.110, 2012: 36.161, 2013: 36.900 (estimate). Clearly half as many got married as got divorced. This cannot be construed as unforeseeable but surely still as self-default. 
Table 4 Whether the profit-making is an evil per se? What is the role of responsibility?

Minibrain has an average but well-paying job, which allows him to make plans for long-term future as well. He and his wife live with their 2 minor kids together.

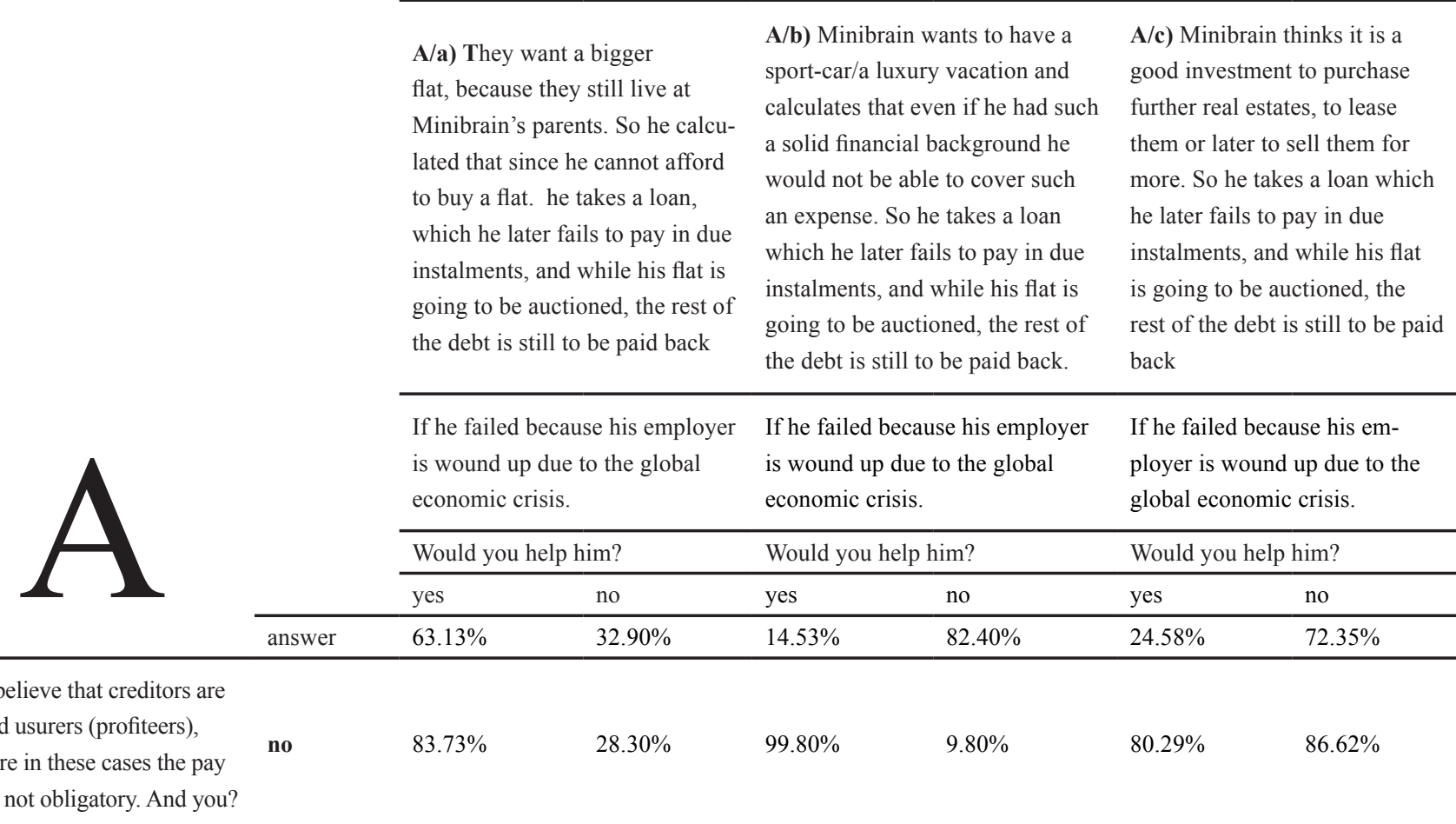

back is not obligatory. And you?

If he failed because his wife got If he failed because his wife got seriously ill and the treatment is seriously ill and the treatment is

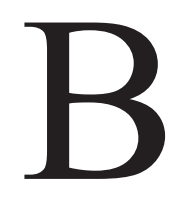
expensive, time consuming and finally he loses his job too. expensive, time consuming and finally he loses his job too.
If he failed because his wife got seriously ill and the treatment is expensive, time consuming and finally he loses his job too.

Would you help him?

\begin{tabular}{lllllll} 
& \multicolumn{2}{l}{ lould you help him? } & \multicolumn{2}{l}{ Would you help him? } & \multicolumn{2}{l}{ Would you help him? } \\
\cline { 2 - 7 } & yes & no & yes & no & yes & no \\
\hline answer & $84.64 \%$ & $11.73 \%$ & $54.75 \%$ & $42.18 \%$ & $62.29 \%$ & $33.52 \%$ \\
\hline
\end{tabular}

Many believe that creditors are rich and usurers (profiteers), therefore in these cases the pay no $82.64 \%$ $85.80 \%$ $21.92 \%$

$85.80 \%$ $83.61 \%$

$88.04 \%$

\section{If he failed because he and his} wife decide to divorce and the

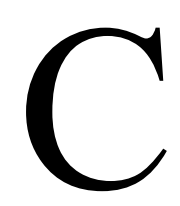
facilitation of the two separate lives imposes significant financial burden.

\section{If he failed because he and his} wife decide to divorce and the facilitation of the two separate lives imposes significant financial burden.
If he failed because he and his wife decide to divorce and the facilitation of the two separate lives imposes significant financial burden.

\begin{tabular}{lllllll} 
& \multicolumn{2}{l}{ Would you help him? } & \multicolumn{2}{l}{ Would you help him? } & \multicolumn{2}{l}{ Would you help him? } \\
\cline { 2 - 6 } & yes & no & yes & no & yes & no \\
\hline answer & $20.95 \%$ & $74.58 \%$ & $12.01 \%$ & $84.64 \%$ & $13.41 \%$ & $80.73 \%$ \\
\hline
\end{tabular}

\section{Many believe that creditors are} rich and usurers (profiteers), therefore in these cases the pay

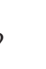

no

\footnotetext{
back is not obligatory. And you?
} 
necessarily blame the creditors for such circumstances. In these scenarios the "no" help groups are in minority and basically these are the most anxious about the creditors' being profiteers and would allow the non-performance of these contracts from the part of the debtors (see explicitly Table 4/A). One might realise right away, that these are the scenarios, where failure of the performance is caused by the global economic crisis. Therefore clearly, here the respondents blame the creditors for the surrounding problems.

The first explanation would be that the respondents simply do not care. They accept that help is needed, meaning also that they would expect to be assisted in such a case, but they do not bother further. This could also reflect that solidarity might well be in their thinking but not in their acting. Therefore implicitly, all these answers boil down to an acceptance or expectation of state interventions. They have no better idea. They do not trust the state but neither the market solutions.

Another possible interpretation may be that the vast majority believes that the contracts should be fulfilled and if impossibility occurs then it is not termination, but rather a possible modification of the contract is needed. And for this, rules are needed, of course. Market rules or state regulations? The first would lead to a circle problem, the latter to the state intervention again, implicitly.

In any event, these possible clarifications do not exclude each other. In the end, both conclusions come to the inevitable reliance in the state measures, even if only implicitly. Those respondents who would be willing to help right away incline to imply to a state measure of intervention into the market affairs. No further enquiry is needed, it is the task of the state to manage somehow. The big split in answering to the method of help (Tables 2/A-2/C) demonstrates the uncertainty of the respondents in this matter.

In the introductory part of the questionnaire, there are some general questions posed to map up the respondents' financial and social backgrounds. The vast majority of the respondents live in a highly indebted environment as debtors. $75.7 \%$ of the respondents said "yes" to the question, if he was aware of any loan taken in the family.

Their mostly negative experience of getting indebted is shown in their answers to the question "to whom would they refer to in case of need for a bridging loan". In case of need the vast majority of them would rather refer to the state first and then to the parents, way ahead of a financial institute (Table 5) ${ }^{14}$.

14 It should be noted, that several answers were allowed to be made here.
Table 5 Who should help you?

\begin{tabular}{lll}
\hline \multicolumn{3}{l}{ In case you needed a bridging loan. } \\
\hline friend & parent & colleague \\
$6.10 \%$ & $26.70 \%$ & $8.90 \%$ \\
employer & state & other \\
$1.70 \%$ & $38.60 \%$ & $59.70 \%$ \\
financial institute & & \\
$8.90 \%$ & & \\
\hline
\end{tabular}

If one considers that the informal financial help (parent) includes also that of the friends and colleagues, this figure basically equals with that of the state. This mirrors well the attitude of the respondents documented in the comments of the answers, namely that in need they would refer privately to friends and parents, because if a serious trouble occurred, they would not necessarily be expected to pay back the full loan. Certainly, it must be added that these respondents are young.

The serious distrust in the state comes into this picture here too. The loan agreement if concluded with the state is less likely to be enforced, than if it were signed with a financial institution (let alone a private one ${ }^{15}$ ). The respondents obviously rely on the vision that in case of financial troubles, one would be able to (re)negotiate with the state (whatever this institution means here for them) just as one could do that with the relatives or friends.

So the question "who is the creditor" may not be irrelevant at all. Therefore special attention should be paid to the answers of the category "other"s. Most of the respondents (59.70\%) would ask money from "other" than friend, parent, colleague, financial institute, employer or state.

It is striking, that in the event of financial difficulties, these youngsters would rather avoid the financial institutes. Clearly, the mistrust in the banks and other financial institutions is palpable among these respondents. This seems to be the culture: the hope (in category "others") for lottery, for a rich uncle abroad, just like in the economically weak Hungary in the beginning of the $20^{\text {th }} \mathrm{c}$. (the Horthy-regime).

This means that these respondents grew up in an environment that tolerates the non-payback, the failure to perform, therefore rather negotiates with those whom they believe they can fail later with possibly no consequences at all (friends and parents) or with less painful consequences (state as opposed to the financial institutions).

Thus conclusively the distrust against the market solutions cannot be worse than against that of the state. Who could trust a state that can renegotiate contracts. When? Under whose mandate? And at whose expense?

15 The arguments here necessary lead too far to the free market concept or state aid, or of the state as a market participant in the private market, etc, which cannot be discussed here. 
Again, this attitude would lead to a sly, 'common sense' behaviour, that one should rather be indebted to the state than not at all, since if not, then he should only be net contributor to the public budget. Whatever simplistic idea this might sound this thinking may be mirrored in the answers in the survey.

It should be noted however, that these responses and comments included also, that in case they were to be asked to lend money to a friend in need, mostly they would not have asked any security for repayment either, again acknowledging the possibility of failure to perform.

\subsection{Readiness to help others in need is relatively widespread if and only the cause is not self-inflicted and the spending is justified}

Looking at the figures and the tables, one has to bear two things in mind. One would be the problem of impossibility to perform, and the other the foreseeability of this risk.

The fact that the impossibility of certain performance could be used as an excuse for the breach of a contract is not at all self-evident (Byrd, 2010). The construing of impossibility as a defense when non-performance is the fault of none of the parties, may qualify as a legal development. Instead of selling the defaulted party as a slave, he can be released from his duties. This changes in construing matters of impossibility is regarded as a legal development of bona fides in Roman Law and of Treu und Glauben (guter Glaube), good faith, fairness or equity in the various legal orders in the $18^{\text {th }}$ and $19^{\text {th }}$ centuries respectively (Földi, 2001).

Notwithstanding the above, the real practical question here is how to solve the problem of an inefficient private loan agreement. And in addition to it, how to solve this problem if this inefficiency is widespread in the economy and affects a great deal of average people, as the data of the survey demonstrates it well (4.2. above).

No doubt that in such market failures a state intevention has already been approved in many modern constitutionalism, especially in those of the welfare states and so in the EU ${ }^{16}$. Legislations, state initiated rules, introduced on behalf of those less able to create a bargaining position in free markets are not brand new, even if they become more and more nuanced (or bureaucratic?) and sometimes less sometimes more intrusive, such as the labour contracts, the consumer protection privisions or the consumer credit protection regulations, let alone the special self-governing rules or ethical codes of certain businesses.

And exactly that is why it is interesting that the respondents of this questionnaire seem to have mistrust in the state regulations almost equally to that of the market solutions, even then when they mostly believe that help is to be granted. Those who

16 See e.g. the latest jurisdiction of the CJEU relating to the long-term (loan) agreements (C-96/14, C-449/13, C-482/13, C-484/13, C-485/13, C$487 / 13$, etc) do not answer "yes" to help do not bother much. But they are in the minority.

\subsection{However well acknowledged it is, that market failures are indispensable, the expected cure from the state regulations are just not trusted.}

Besides the private debt issues, the survey was intended to spread out to the business debts and loans too.

The playing field here is designed rather for the smaller companies (SMEs). In this fictitious case again, the owner of a company has an own patent and an excellent long-term business model. Although the company had it well for a while, still, due to a decreasing demand, the turn over of the company was plummeting and turned into a loss. The owner takes more andmore loans but without further investments the company faces bankruptcy. Since the firm's assets is subject to a secured loan taken before, the company cannot receive further commercial credit or only at an extra price.

In this case the questions focused on the rules of being able to get a loan, on the administrative restrictions, if any, and on the responsibility (or even liability) of a company making solid business decisions or on the responsibility of the state to watch over these problems, if not more (see Table 6/A-6/C).

The majority of the respondants $(71.2 \%)$ would not claim that the problems of the SMEs here are caused by the administrative rules. This may be interpreted in two ways though. One is that the majority accepts the market rule. The manager made bad business decisions. The other one is that the majority accepts the administrative rules as a fact but simply thinks that here this was not the cause. This is not to wonder. The question of course is always a matter of degree.

What is more telling here however (Table 6/A.), is that this group of majority which does accept the need for regulations and does not blame the adminitrative prescriptions would nevertheless incline to believe that one needs to lie ("declare non-realistic statements") in formal loan requests $(30.50 \%)$, which is $\sim 21 \%$ of all responses. Truly though, they are in the minority, but what a minority! Truly, also $62.90 \%$ of them (which is $43 \%$ of all responses) believe that not disclosing a relevant fact in such a request form means fraud and one should be liable for that. But that is barely more than the half of the majority who accepts the rules, and not even the half of all answerers.

Now, those who do complain about the administrative rules are even more interesting. Evidently this is a tiny little group (of about 70 respondents) but are more convinced that the rules might require false statements to make (44.52\%) and they also think, that this should qualify as a lie and be punished (49.57\%). What kind of attitude should there be expected here if someone is determined to carry out a transparent but successful business?

And finally if one looks at the last question, it is obvious that the overwhelming majority of the respondents accept the 
Megabrain has an own patent and an excellent long-term business model. Thus his small garage-firm leases the seat and the two cars of the company. The company had made good profit for some years but recently, due to the decreasing demand, the income of the company was plummeting and turned into a loss in the last couple of years. Although there is quite a competition in the market, Megabrain manages to obtain a bridging loan from a bank owe to his good will and connections. However Megabrain does not disclose that his patent rights are going to expire and he has no intention to extend it. Without further investments, the company apparently goes bankrupt. Since the firm's assets is subject to a secured loan taken before, the company cannot receive other commercial credit or only at an extra price. In this case

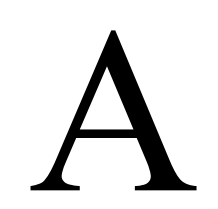

\begin{abstract}
Many would blame the rules, claiming that they set administrative obstacles for the small entrepreneurs. And You?
\end{abstract}

yes $(21.6 \%)$ in total population
Many would blame the rules, claiming that they set administrative obstacles for the small entrepreneurs. And You? Many believe that debtors in a loan agreement often feel
compelled to declare non-realistic statements. And You? yes

$44.52 \%$ no $(71.2 \%)$ in total population

Many believe that Megabrain should be liable for fraud. And You?

$62.90 \%$

Many believe that Megabrain had happened to be lucky and that lately made series of bad business decisions, and that he should have either left the business earlier or should have invested more by working harder and

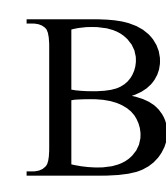

Many would blame the rules, claiming that they set administrative obstacles for the small entrepreneurs. And You?
Many would blame the rules, claiming that they set administrative obstacles for the small entrepreneurs. And You?

\begin{tabular}{|c|c|c|c|}
\hline $\begin{array}{l}\text { Many believe that it is the state that has the duty to } \\
\text { take care of small entrepreneurs in need. And You? }\end{array}$ & yes & $76.65 \%$ & $51.36 \%$ \\
\hline tax allowance & yes & $57.37 \%$ & $31.52 \%$ \\
\hline non-refundable support & yes & $29.37 \%$ & $13.23 \%$ \\
\hline appointment of state liquidator & yes & $11.47 \%$ & $11.28 \%$ \\
\hline \multirow[t]{3}{*}{ buy out } & yes & $5.05 \%$ & $7.00 \%$ \\
\hline & & $\begin{array}{l}\text { Many would blame the rules, claiming } \\
\text { that they set administrative obstacles for } \\
\text { the small entrepreneurs. And You? }\end{array}$ & $\begin{array}{l}\text { Many would blame the rules, claiming that } \\
\text { they set administrative obstacles for the } \\
\text { small entrepreneurs. And You? }\end{array}$ \\
\hline & & yes $(21.6 \%)$ in total population & no $(71.2 \%)$ in total population \\
\hline
\end{tabular}

Should there be an insurance fund financed by the market participants (companies), which in return, in case of bankruptcy, may grant favourable credit to the

market rules by claiming that the business decision of the manager was not adequate. So the overwhelming majority accepts the market rules but not the solution.

It is just conspicuous, how the majority of the respondents, regardless whether they trust the regulations or not, expect the state most of all, implicitly or not, to manage the regulations of the business. No doubt that the acceptance of a kind of a state duty to take care of small and medium entrepreneurs is more widespread among the respondents than not (Table 6/B) ${ }^{17}$. And surprisingly enough (or not?), it is less so (51.36\%) among those who are less suspicious about the administrative restrictions (71.2\%).

One way to look at it is that those who do blame the administrative obstacles in SMEs business expect more help and are more critical towards the existing rules. Thus in this case one might ponder a little bit whether the distinction between the two groups

17 Please note, that here more answers were possible. 
are a sign of different attitude towards the market and the state or rather it is the critical attitude towards a well rooted culture biased to state intervention which divides the "yes" and "no" groups.

This thinking might be tested in the responses of the "how". Should the state provide for tax allowance or state aid or manage more administrative intervening measures such as the appointment of state liquidator or carry out a buy-out. None of these may be considered as more market-friendly than the others, in the end all of these measures result in the taxpayers' help.

This is why it is more than striking to have a look at the answers in Table 6/C. When there is a rather market like solution of a saving management (sort of insurance, but obligatory) for a possible bankruptcy, the embracement of this institution is quite broad as opposed to that of a strict state aid (no matter what that might really mean).

\section{Who shall have the burden then?}

All in all, one needs to come to the conclusion from the answers above that the majority of the respondents favours implicitly the state solutions as opposed to the market one, but trusts none of them.

No doubt that the overwhelming majority of the respondents accepts the market rules but not the solutions. Or rather, they accept the advantages of the market economy but refuse to live with their disadvantages. This is no wonder.

The question is whom to put the burden of remedying the bad individual decisions, when the pushing away of the responsibility is quite widespread. This question is even more interesting if one considers the fate of windfalls. Undoubtedly, if any windfall derived from this kind of decisions benefited the debtors but not the creditors, would be awarded to the debtors right away with no hesitation at all, as it was the case before the global crisis in the so called long-term consumer loan agreements based on the foreign exchange rates.

As mentioned at the very beginning, and as is often obvious in the answers, the respondents compose a new generation in the sense, that they were born after the Transition. This generation grew up in the stumbling first steps of the democracy and the market operations. This generation is uniquely overburdened with private debt, most of which will never be paid back.

This also reflects the fact that in the childhood of these respondents (from the 1990s to the early 2000s) there were no solid foundations for a healthy financial understanding in a fastly growing globalisation. After having spent several decades in a command economy, then a little bit looser state-steered economy, Hungary has joined the free market economies in a time of a decreasing inflation, overall optimism about the capitalistic future, and in a swiftly growing world wide consumption. As opposed to this global economic background the country had faced serious structural economic crisis (pension, health care, education), long term financial problems, budgetary restrictions, several austerity packages without real solutions.

\subsection{The minimum living existence as a fundamental (constitutional) right}

The lack of private housing for youngsters has ever been a problem of the Kadar-regime, thus during (and after) the Transition this was one of the issue number one in politics too. The then newly established Consitutional Court has inherited already cases from its legal ancestor of the previous regime, dealing with the then long-term loan agreements. The issuse was how to adapt the state subsidized (socialist) loan agreements to the market environment ${ }^{18}$.

And this want of an own housing behaviour, this culturally over estimated precious goods, is reflected well in the manner of the young generation too. Housing is always more supported by the respondents than not (first column in Table 7/A), in case of illness this solidarity even grows (second column in Table 7/A), but plummets considerably if they think the default was self-inflicted, as for example in the case of a divorce (third column in Table 7/A).

\subsection{The luxurious expenses at the expense of others}

The issue of luxurious expenses financed out of a long-term loan is a lot more complicated. Here the statements and actions do not seem to be in harmony with each other.

One way to look at it is that the negative impact of the circumstances triggers always sympathy. And it is true for quite a wild range of issues, it may be financial (economic crisis), biological (illness) or sociological (divorce) problem as certainly evidenced in the table below (Table 7/B).

Why would someone justify a common solidarity for an irrational use of others money (i.e. loan)? If one considers the cultural and historical background one is compelled to see a pattern. The deisre to act and live like a rich man even at the expense of others is well rooted in the history. Truly, the vast majority would not support this idea.

However, looking at the first column, at the responses in the case of "no"s, it is striking how definitely - almost in consent - the blame is put on the creditors if the trouble was caused by the financial crisis. This means, that this young generation

18 See the constitutional Court case No. 32/1991. (VI. 6.) ABH. The case in question was about the enormous economic and financial discrepancy in the terms and conditions provided for in the newly entered long-term loan agreements on the one hand and those concluded still in the socialist regime on the other hand. The interest rate on the old loan was close to none, whereas it was around $30-35 \%$ in the new loan agreements. The legal issue here was, as is now too, whether it is justified for the state to intervene into private agreements and enforce amendments by legislation against even the wills of the (both) parties. The very circumstances differ though in a great deal, since the Transition back then had proved to be unforeseeable for the parties at the conclusion of their contracts, but never again this argument was ever accepted by the Constitutional Court until now. The article 226.§ (2) of the Civil Code of 1959 then in effect was even found by a judge back then constitutionally dubious, as a matter of fact, which however granted the means necessary for the transition to a market economy. 
Table 7 Who should have the burden of failure?

Minibrain has an average but well-paying job, which allows him to make plans for long-term future as well. He and his wife live with their 2 minor kids together.

If he failed because his If he failed because he and his

If he failed because his employer is wound up due to wife got seriously ill and wife decide to divorce and the the global economic crisis.

the treatment is expensive, time consuming and fi-

nally he looses his job too. facilitation of the two separate

lives imposes significant

financial burden.

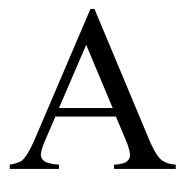

A/a) They want a bigger flat, because they still live at Minibrain's parents. So he calculated that since he cannot afford to buy a flat. He takes a loan, which he later fails to pay in due instalments, and while his flat is going to be auctioned, the rest of the debt is still to be paid back

Would you help him? Would you help him? Would you help him?

\begin{tabular}{|c|c|c|c|c|c|}
\hline answer & yes & no & yes & no & yes \\
\hline
\end{tabular}

$\begin{array}{llllll}63.13 \% & 32.90 \% & 84.64 \% & 11.73 \% & 20.96 \% & 74.58 \%\end{array}$

\begin{tabular}{l} 
Would you reconsider it, if you kn \\
not pay because he saved money for \\
illness and education for his child \\
\hline Would you support an individual b \\
Would you support a preferential \\
debtors? \\
Many believe that creditors are rich \\
(profiteers), therefore in these cases \\
not obligatory. And you?
\end{tabular}

\begin{tabular}{|c|c|c|c|c|c|c|c|}
\hline & \multirow{2}{*}{\multicolumn{2}{|c|}{$14.53 \%$}} & \multirow[b]{2}{*}{$82.40 \%$} & \multirow[b]{2}{*}{$54.75 \%$} & \multirow[b]{2}{*}{$42.18 \%$} & \\
\hline & & & & & & $12.01 \%$ & $84.64 \%$ \\
\hline $\begin{array}{l}\text { Would you reconsider it, if you knew that he could } \\
\text { not pay because he saved money for retirement, ill- } \\
\text { ness and education for his children? }\end{array}$ & yes & $50.19 \%$ & $1.10 \%$ & $11.79 \%$ & $9.79 \%$ & $31.39 \%$ & $8.43 \%$ \\
\hline Would you support an individual bankruptcy? & yes & $65.96 \%$ & $5.20 \%$ & $16.39 \%$ & $25.83 \%$ & $50.65 \%$ & $29.22 \%$ \\
\hline $\begin{array}{l}\text { Would you support a preferential tax system for } \\
\text { debtors? }\end{array}$ & no & $58.17 \%$ & $7.90 \%$ & $14.73 \%$ & $81.03 \%$ & $44.82 \%$ & $79.22 \%$ \\
\hline \multirow{5}{*}{$\begin{array}{l}\text { Many believe that creditors are rich and usurers } \\
\text { (profiteers), therefore in these cases the pay back is } \\
\text { not obligatory. And you? }\end{array}$} & no & $99.80 \%$ & $9.80 \%$ & $21.92 \%$ & $85.80 \%$ & $82.04 \%$ & $87.65 \%$ \\
\hline & & \multicolumn{6}{|c|}{$\begin{array}{l}\text { A/c) Minibrain thinks it is a good investment to purchase further real estates, to lease them } \\
\text { or later to sell them for more. So he takes a loan which he later fails to pay in due instal- } \\
\text { ments, and while his flat is going to be auctioned, the rest of the debt is still to be paid back }\end{array}$} \\
\hline & & \multicolumn{2}{|c|}{ Would you help him? } & \multicolumn{2}{|c|}{ Would you help him? } & \multicolumn{2}{|c|}{ Would you help him? } \\
\hline & answer & yes & no & yes & no & yes & no \\
\hline & & $24.58 \%$ & $72.35 \%$ & $62.29 \%$ & $33.52 \%$ & $13.41 \%$ & $80.73 \%$ \\
\hline $\begin{array}{l}\text { Would you reconsider it, if you knew that he could } \\
\text { not pay because he saved money for retirement, } \\
\text { illness and education for his children? }\end{array}$ & yes & $38.94 \%$ & $8.51 \%$ & $34.25 \%$ & $4.55 \%$ & $43.61 \%$ & $9.99 \%$ \\
\hline Would you support an individual bankruptcy? & yes & $48.08 \%$ & $32.30 \%$ & $51.57 \%$ & $21.29 \%$ & $49.62 \%$ & $26.97 \%$ \\
\hline $\begin{array}{l}\text { Would you support a preferential tax system for } \\
\text { debtors? }\end{array}$ & no & $46.63 \%$ & $73.78 \%$ & $42.36 \%$ & $84.21 \%$ & $49.62 \%$ & $79.15 \%$ \\
\hline $\begin{array}{l}\text { Many believe that creditors are rich and usurers } \\
\text { (profiteers), therefore in these cases the pay back is } \\
\text { not obligatory. And you? }\end{array}$ & no & $80.29 \%$ & $86.62 \%$ & $83.61 \%$ & $88.04 \%$ & $78.95 \%$ & $87.89 \%$ \\
\hline
\end{tabular}


overwhelmingly holds the creditors (most likely the fiancial sectors in this case) responsible for the global economic crisis, and the debtors of such contracts as victims. Therefore the obligations may be forgiven. And what is more, probably that is why, it is here where the preferential tax regime is the most advocated.

And if it is so, which is very much evidenced here, the question is, those who would help (and do not think that the obligations are to be forgiven, see second column group "yes") would do that for what reason? As a matter of fact, this proves to be the group of people with real sympathy to others problems. The proper means for help is not clear though. The group is divided in almost all measures by half and half.

Further interesting results are in the third column of Table 7/B. Here, it seems, the respondents regard the speculator/investor as being part of the problem rather than a victim. So the help is missing here the most.

\subsection{Speculation or investment (business without the legal formalities)}

Originally, this question is to analyse the attitude towards hustlers, slickers ("ügyeskedők"). In this situation the debtor, without setting up a proper business as required by the law, acts as a "businessman" and uses the possibility to make money in a much friendlier, easier environment, clearly at the expense of others.

No doubt, this hustler manner is fairly well scattered in the Hungarian society, nevertheless the respondents do not quite seem to realise it. Unquestionably, most of them would cathegorise this situation as a speculation not worthy of help and as a problem caused by own fault, and the debtor himself as the problem maker rather than the victim.

This doubt of presumption however, whether here the respondents are biased against business or speculation as such or just really identified the actors as hustlers, thereby not worthy of help, remains still to be developed.

\section{Conclusions}

As for a really brief conclusion of the survey, one could say that the respondents act very logically and calculate very rationally. They do so, even if they mostly have no basic knowledge of the issues above but a hunch. The problem is that acting irresponsibly is rational because it pays off better than acting by the rules. To be able to embrace the disadvantages of the market economy one needs to be able to understand and manage them institutionally. This survey, as it stands now, demonstrates exactly the lack of such an insight.

The results depict a latently, vaguely rather messianistic, though not trusted, expectation from the state, whatever that should mean. This vague expectation for a solution may certainly be interpreted also as a general need to push the responsibility away. This suggestion may well be demonstrated by the answers, which show a relatively ready help but also a split mostly in half and half in the "how"s. The "how" is just does not matter. So it might reflect just a general desire of goodness without the thorough understanding of or deliberations of the (unintended) consequences ${ }^{19}$.

Clearly these youngsters have no experiences of themselves so far, so the responses mirror rather a cultural heritage ${ }^{20}$.

In these circumstances loan is an alternative, but exactly in these circumstances this loan is a very expensive alternative. Without trust (and it means here saving/investment too) in the system, the price of the loan is just going to be soaring, because it may be excused to fail the agreement regardless the consequences.

As to a final impression and conclusion, one faces a very blurred picture. Albeit it is clear that the overwhelming majority of the respondents accepts that the long-term promises are binding, still quite many of them are ready to appreciate the troubles of the debtor, especially if those troubles were caused by the global economic crisis or illness. None of these causes are considered by the respondents as a risk which needs to be (or should be) calculated or managed privately right before the entering into a contract. Thus it seems that the majority of the respondents feel deeper for those in - not self-inflicted - needs. What own fault means however is not very clear and distinctive. This sympathy is also clouded by the fact that the solutions in these situations are not consequential. Their desire to help therefore are not supported by the reality but by some vague expectations from the public funds, the public hand (darely paraphrasing Smith).

So, as it seems, the operation of the market is widely approved, working for profit is not at all cursed, provided, there are no failures. If market failure occurred, the solution is not expected from the market but rather from a vague conception of the state aid.

One might think right away, that basically this is what one witnesses also in the developed, welfare states too. In case of market failure the regulation is felt to be necessary and right. The difference is however, that here there is a traditional misgiving about the governmental interferences or reactions. Not because of the fear from the state intervening into the private autonomy, but because the state proves to be incompetent.

Assuming that these conclusions are justified, the results are quite thought-provoking. A quarter of a century after the Transition, the new generation's reactions to the occuring financial-social problems have roots in the past socialism rather than in the capitalism. The reasons why the Transition - due to the global collapse of the Soviet regime - was so

19 The eagerness to insulate the decision-makers from the negative consequences of their own bad economic decisions is so vivid, that it is quite a topic again in the public discourse relating to the amendments of the brand new Civil Code. See Article. 2. of the bill No. T/10528 of the government concerning Article 3:24. on the liability of the company management in various cases.

20 This lack of trust in the state operation is surveyed - among others - by András Sajó (Sajó, 2008). 
undeniably overwhelmingly popular are just gone. The deep distrust in a paternalistic state, the devastating experiences of state intrusion, the dislike of socialist "Gleichschaltung", the desire to motivate creativity so that to enhance individual independence, autonomy and self-esteem are not even traceable. What is left nowadays is the capitalistic objectives (an avidity to be wealthy) without the capitalistic virtues (the autonomous, financially independent, deliberating citizen).

\section{Acknowledgement}

Special thanks should be devoted to András Bleyer, Professor of Mathematics, who was so enthusiastic about making sense of the data gathered through the surveys, and without whose help these tables below would not be so legible. This goes without saying, of course, that all responsibility for the possible misunderstanding or misinterpretation of these data is entirely mine.

\section{References}

Byrd, S. B. (2010). Einführung in die Anglo-Amerikanische Rechtssprache (Introduction to Anglo-American Law and Language) Band II/Vol II. Contracts and Torts. 2. Auflage. p.371. C.H.Beck -Stämpfli. (in German)

Byrne, D. M. (1999). Locke, Property and Progressive Taxes. Nebraska Law Review. 78(3), pp. 700-738.

Csehi, Z. (2015). A vezető tisztségviselő polgári jogi felelősségének alapjai és irányai az új Polgári Törvénykönyv alapján. (Legal Foundations and Trends of Civil Law Liability of the Chief Executive Officer according to the new Civil Code.), In: Csehi, Z., Szabó, M. (eds.) A vezetó tisztségviselö felelössége. (Liability of the Chief Executive Officer.) (pp. 9-50.) CompLex Wolters Kluwer, Budapest. (in Hungarian)

Fleck, Z., Gajduschek, Gy. (2015). Empirikus kutatás a jogban. (Empirical Research in Law.) In: Jakab, A., Menyhárd, A. (eds.) A jog tudománya: Tudománytörténeti és tudományelméleti írások, gyakorlati tanácsokkal. (Jurisprudence.) (pp. 101-131.) HVG-ORAC Lap- és Könyvkiadó Kft. (in Hungarian)

Földi, A. (2001). A jóhiszemüség és tisztesség elve. Intézménytörténeti vázlat a római jogtól napjainkig. (The Principle of Bona Fidei. A Historical-institutional Outline from the Roman Law upto Now.) ELTE Állam- és Jogtudományi Kar, Budapest. (in Hungarian)

Földi, A. (2004). A másért való felelösség a római jogban, jogelméleti és összehasonlitó polgári jogi kitekintéssel. (Liability for Others in Roman Law.) Rejtjel, Budapest. (in Hungarian)
Griffiths, M. R., Lucas, J. R. (1996). Ethical Economics. Palgrave-MacMillan. Hatzis, A. N. (2015). Moral Externalities: An Economic Approach to the Legal Enforcement of Morality. In: Hatzis, A. N., Mercuro, N. (eds.) Law and Economics: Philosophical Issues and Fundamental Questions. (pp. 226244.) Routledge, London/New York. [Online]. Available from: http:// ssrn.com/abstract=2821292 [Accessed: 23 rd August 2016.]

KSH (2013). Statisztikai Tükör. (Statistical Mirror.) Népmozgalom. (People’s movement.) Budapest. (in Hungarian)

Pázmándi, K. (2015). A nyelvvel való visszaélés rétegei a pénzpiacokkal kapcsolatos kereskedelmi és politikai kommunikációban. (Layers of abusing language in commercial and political communications related to the money-markets). In: Szabó, M. (ed.) A jog nyelvi dimenziója. (Dimension of the Language of Law.) (pp. 257-266.) Bíbor Kiadó, Miskolc. (in Hungarian)

Picketty, T. (2015). Economy of Inequality. Harvard University Press

Picketty, T. (2014). The Capital in the 21st Century. Harvard University Press.

Sajó, A. (2008). Az állam müködési zavarainak társadalmi újratermelése. (Social reproduction of state operating functions). Közgazdasági Szemle. 55(7-8), pp. 690-711. (in Hungarian)

Schoenblum, J. (1995). Tax fairness or unfairness? A consideration of the philosophical bases for unequal taxation of individuals. The American Journal of Tax Policy. 12, pp. 221-271. 